\title{
Validation of a method for simultaneous analysis of cocaine, benzoylecognine and cocaethylene in urine using gas chromatography-mass spectrometry
}

\author{
Vinicius Stela Menotti ${ }^{1}$, Deborah Thais Palma Scanferla ${ }^{1}$, \\ Kleber Ota de Oliveira1, Gabriela Felber Fratucci², Gessé de Souza Alves², \\ Erika Bando ${ }^{2}$, Samuel Botião Nerilo ${ }^{2,3}$, Magda Lúcia Félix de Oliveira ${ }^{4}$, \\ Miguel Machinski Junior², Simone Aparecida Galerani Mossini ${ }^{\circledR 1,2^{*}}$
}

${ }^{1}$ Postgraduate Program on Bioscience and Physiopathology, State University of Maringa, Maringa

- Parana, Brazil, ${ }^{2}$ Laboratory of Toxicology. Department of Basic Health Sciences, State University of Maringa; Maringa - Parana, Brazil, ${ }^{3}$ University Center Ingá, Maringá - Paraná, Brazil, ${ }^{4}$ Postgraduate Program on Nurse, State University of Maringa, Maringa-Parana, Brazil

\begin{abstract}
The present study describes a method for simultaneous analysis of cocaine, benzoylecgonine and cocaethylene in urine samples. After solid phase extraction, Gas Chromatography-Mass Spectrometry was used for identification and quantification. The calibration curves were linear at 20 - $3000 \mathrm{ng} / \mathrm{mL}, \mathrm{r} 20.9997$ for benzoylecgonine, 15 - $2000 \mathrm{ng} / \mathrm{mL}, \mathrm{r} 20.9985$ and r2 0.9993 for cocaine and cocaethylene, respectively. Accuracy values: cocaine: 93,5 - 102,1\%; benzoylecgonine: 97,5 104,8\%; cocaethylene: 90,6 - 101,5\%. Precision values: cocaine: C.V 5,4 - 14,6\%; benzoylecgonine: C.V 7,8 - 12,3\%; cocaethylene: C.V 5,9 - 12,3\%. Detection and quantification limit values: cocaine and cocaethylene:10 ng/mL and $15 \mathrm{ng} / \mathrm{mL}$, respectivalty; benzoylecgonine: $15 \mathrm{ng} / \mathrm{mL}$ and $20 \mathrm{ng} / \mathrm{mL}$, respectivaley. Recovery values: cocaine: 78,0 - 85,8\%; benzoylecgonine: 74,0 - 79,8\%; cocaethylene: $83,0-91,5 \%$. The method described is advantageous compared to others, as it simultaneously detects the major analytes found in urine samples due to cocaine use and has been successfully validated.
\end{abstract}

Key-words: Analytical validation. GC-MS. Cocaine.. Human urine

\section{INTRODUCTION}

The United Nations Office on Drugs and Crime (UNODC) World Drug Report 2017 provides an estimate that in 2015 about 250 million of casual users who have consumed illicit drugs at least once throughout the year,

*Correspondence: S. A. G. Mossini. Laboratório de Toxicologia. Departamento de Ciências Básicas da Saúde. Universidade Estadual de Maringá. Avenida Colombo, 5790, Jardim Universitário. 87020-900 Maringá-Parana, Brasil. Phone:: +55 (44) 3011-4565/3011-4489. Fax: 30116029. E-mail: simonegmossini@gmail.com. Contributions: VSM, SBN, MMJ and SAGM designed the study. VSM, KOO, DTPS, GFF and GSA acquired the data. VSM, EB and SBN analyzed the data, and VSM, MMJ, MLFO and SAGM contributed to the writing of the manuscript. which corresponds to $5.2 \%$ of the global population. The consumption of drugs of abuse also varies according the sex, that is, males are two to three times more likely to consume drugs of abuse than females (UNODC, 2017).

The use of analytical methods for determination of drugs of abuse in biological samples is an important means for prevention, diagnostics and treatment, which helps assessing involvement of drugs in circumstances, such as traffic accidents and development of social programs aimed at preventing drug abuse (Follador et al., 2004).

The most common approach to drug analysis recommended by the National Institute on Drug Abuse 
(NIDA) in the USA refers to the association of screening analyses followed by confirmatory tests. Screening analyses are usually based on immunoenzymatic methods, however the results are preliminary. If a result is positive for a certain substance, it is necessary that confirmation through a more specific technique is carried out, such as gas chromatography coupled to mass spectrometry (GC-MS) (De Brabanter et al., 2013).

However, a validation process must be carried out in order to guarantee the efficacy of an analytical method so as it is introduced in a lab routine Standards for new analytical methods have become increasingly rigid, as non-trustworthy analytical data can lead to therapeutic decisions with disastrous impacts on patient health. Financial losses due to dubious analytical data are also a concern (World Health Organization 1992).

Therefor, a validation process for simultaneous determination of cocaine (COC), its biotransformation metabolite benzoylecgonine (BZE), and cocaethylene (CE), which is an active metabolite byproduct of concurrent consumption of cocaine and alcohol, in urine by GC-MS has been carried out.

Simultaneous determination of analytes hastens the routine of lab analyses, since it allows for various different analytes to be assessed in a same sample, increasing methodological efficacy.

\section{MATERIAL AND METHODS}

\section{Reagents}

Methanol, dichloromethane, isopropanol, ammonium hydroxide and ethyl acetate were purchased from AppliChem Panreac Itw Companies ${ }^{\circledR}$. Chloridric acid, monobasic potassium phosphate and dibasic sodium phosphate were purchased from Anidrol Laboratory Products ${ }^{\circledR}$. Benzoylecgonine (BZE), cocaine (COC) and cocathylene (CE) and their respective internal standards (BZE- d3, COC-d3 and CE-d3, $1 \mathrm{mg}$ / $\mathrm{mL}$ or $0.1 \mathrm{mg} / \mathrm{mL}$ in acetonitrile) were purchased from Cerilliant Analytical Reference Standards ${ }^{\circledR}$ (Round Rock, TX, USA). The extraction cartridges used were Bond Elut Certify ${ }^{\circledR}$ (Agilent, Folsom, California, USA) and bis-trimethylsilyl-trifluoroacetamyde (BSTFA) were from Supelco ${ }^{\circledR}$ (Bellefore, PA, USA) in addition to trimethylchlorosilane (TCMS) by Sigma Aldrich ${ }^{\circledR}$ (St Louis, Missouri, USA).

\section{Biological samples}

Urine samples not containing any of the assessed analytes were randomly collected from voluntaries who were not drug users at the Laboratory of Toxicology of the State University of Maringa - UEM. Samples were stored at $-20{ }^{\circ} \mathrm{C}$ until further analyses were carried out. The study was approved by the Committee on Ethical Research with Human of the State University of Maringa, under CAAE number 06218713.0.0000.0104, opinion number $n^{\circ} 458.185$.

\section{Analyte extraction}

A volume of $2.5 \mathrm{~mL}$ of urine was placed in 15 $\mathrm{mL}$ centrifuge tubes alongside $37.5 \mu \mathrm{L}$ of BZE- $\mathrm{d} 3(10$ $\left.\mu \mathrm{g} \cdot \mathrm{mL}^{-1}\right), 37.5 \mu \mathrm{L}$ of COC-d3 $\left(10 \mu \mathrm{g} \cdot \mathrm{mL}^{-1}\right)$ and $2.0 \mathrm{~mL}$ of distilled water. Considering mass fragments detection, the ideal is to use at least an internal standard analogous for the molecule of the analyzed analyte, so deuterated cocaine (COC-D3) was used as an internal standard for cocaine and for cocaethylene. (CHASIN et al., 1994). The $\mathrm{pH}$ of samples was adjusted to remain ranging between 6.0 to 7.0 . Next, $2.0 \mathrm{~mL}$ of sodium phosphate buffer 0.1 mol.L $\mathrm{L}^{-1} \mathrm{pH} 6.0$ were added to the final solution. The extraction cartridges were conditioned by first adding $2.0 \mathrm{~mL}$ of methanol until the whole volume had flowed through the cartridge; next, $2.0 \mathrm{~mL}$ of sodium phosphate buffer $0.1 \% \mathrm{pH} 6.0$ were added to the cartridge. Urine drops were added to the cartridge at a flow of one drop per second with the aid of a Pasteur pipette. For washing, $6.0 \mathrm{~mL}$ of distilled water were passed through the cartridge, followed by $3.0 \mathrm{~mL}$ of $\mathrm{HCl} 0.1 \mathrm{~mol}^{-\mathrm{L}^{-1}}$ and then by $3.0 \mathrm{~mL}$ of methanol. Elution was carried out with $3.0 \mathrm{~mL}$ of a dedichloromethane/isopropanol/ammonium hydroxide solution $(12: 3: 0.3 \mathrm{~mL})$ freshly prepared. The final aliquot was submitted to evaporation at $40{ }^{\circ} \mathrm{C}$ in a water bath and stored in a freezer until further use. When the samples were to be analyzed, $25.0 \mu \mathrm{L}$ of BSTFA $1 \%$ TCMS were added for derivatization, and $25 \mu \mathrm{L}$ of ethyl acetate were added while the samples remained in a heating plate at $90{ }^{\circ} \mathrm{C}$ for 15 minutes. Next, the whole volume was transferred to a $2.0 \mathrm{~mL}$ vial which was then placed in a GC-MS apparatus for sample analysis.

\section{Instrumentation}

The solid phase extraction (SPE) method used in this study was proposed by Yonamine and collaborators 
(Yonamine, 2004) with adaptations, since the mixed phase extraction cartridges Bond ElutCertify ${ }^{\circledR}$ $130 \mathrm{mg} / 30 \mathrm{~mL}$ (CX 50) (173gr) - Agilent were used. The process of analytical validation was carried out using a gas chromatograph Focus coupled to a mass spectrometer DSQ II, both by ThermoScientific ${ }^{\circledR}$ (USA), also employing a capillary column for gas chromatography HP-5MS and a Triplus AS injector.

\section{Analytical conditions}

Gas chromatograph: Injection mode: Splitless. Carrier gas: Helium, constant flow rate of $0.6 \mathrm{~mL} / \mathrm{min}$. Injector temperature: $270{ }^{\circ} \mathrm{C}$. Furnace temperature programing: $150{ }^{\circ} \mathrm{C} / 1 \mathrm{~min}, 10{ }^{\circ} \mathrm{C} / \mathrm{min}$ until $270{ }^{\circ} \mathrm{C} / 4 \mathrm{~min}$. Total run time: 17 minutes. Transfer line temperature: $280{ }^{\circ} \mathrm{C}$.

Mass spectrometer: electronic ionization mode (EI), fullscan operation mode, masses selected from 50 to 550 $(\mathrm{m} / \mathrm{z})$, temperature of the ionization source of $220^{\circ} \mathrm{C}$.

\section{Validation procedures}

The parameters assessed throughout validation of the analytical methods are recommended by Resolution $\mathrm{n}^{\circ} 27$ of May $17^{\text {th }}$ of 2012 published by the National Agency of Health Surveillance (ANVISA, 2012), according to both, the national Guide on Procedures and Validation of Bioanalytical Methods and the international guidelines (UNODC, 2017). In order to validate the analytical procedures, the following parameters were assessed: linearity, precision, accuracy, detection limit and quantification limit. Recovery and stability assays were also carried out (ANVISA, 2012).

\section{Linearity}

For assessing linearity, a linearity curve was drawn using negative urine samples to which standards were added at six different concentrations: 20, 150, 200, 800, 1600 and $3000 \mathrm{ng} / \mathrm{mL}$ for BZE and 15, 50, 150, 500, 1000 and $2000 \mathrm{ng} / \mathrm{mL}$ for COC and CE. The assay was carried out in ten replicates for each concentration.

\section{Intra/inter assay precision}

Precision was defined as coefficient of variation $(\mathrm{CV})$, and intra and inter assay precisions were assessed at three different concentration levels (low, average, high), considering the limits established by the calibration curves for each analyte. Six readings were assessed for each concentration. For BZE, samples at concentrations of 150, 800 and $3000 \mathrm{ng} / \mathrm{mL}$ were used, whereas for COC and CE, samples at concentrations of 50,500 and $2000 \mathrm{ng} / \mathrm{mL}$ were used. All analytes were assessed at three different days.

\section{Accuracy}

The accuracy assay was carried out throughout three consecutive days using low, average and high concentrations of the specified analytes, with six determinations per concentration. For BZE, concentrations of 150,800 and $3000 \mathrm{ng} / \mathrm{mL}$ were used, and for $\mathrm{COC}$ and $\mathrm{CE}$, concentrations of 50, 500 and $2000 \mathrm{ng} / \mathrm{mL}$ were used.

\section{Limit of detection (LOD) and limit of quantification (LOQ)}

In order to acess LOD, the standards used must be diluted until a minimal detectable concentration level is reached, which must stand at a point below the last point of the calibration curve that is being built. LOD was determined by analyzing the solutions of known decreasing concentrations of the analytes until the lowest detectable concentration was reached. LOQ was determined by assessing urine samples fortified with analytes at decreasing concentrations; this limit was evaluated in sextuplicates and the coefficient of variation must not be above $15 \%$.

\section{Recovery Assays}

Recovery assays were performed by preparing two batches of urine samples of equal concentrations. One batch (batch A) consisted of samples containing three concentrations for each analyte, and it was analyzed in sextuplicates. The second batch (batch B) also consisted of samples containing three concentrations for each analyte, however the analytes were added immediately after the SPE procedure was carried out. Absolute recovery of the analytes was assessed by comparing the average results obtained for batch A (processed) and B (non-processed).

\section{Stability}

For stability assays, analytes were added to urine samples to a final concentration of $150 \mathrm{ng} / \mathrm{mL}$ and then were stored and kept at $4-8{ }^{\circ} \mathrm{C}$, which are routine 
storage conditions for this kind of sample. Throughout seven days, the stored urine samples were analyzed for analyte concentrations in triplicates, and the final concentration values were compared to the values obtained from readings from freshly prepared urine samples (150 $\mathrm{ng} / \mathrm{mL}$ per analyte) previously stored at $-20{ }^{\circ} \mathrm{C}$ (the concentration of the analytes in this sample was considered $100 \%$ ).

\section{Statistical analyses}

Regarding statistics, raw data were obtained by using the softwares for each equipment and plotted in Microsoft Excel ${ }^{\circledR} 2010$.

\section{RESULTS AND DISCUSSION}

Final analytical validation values for coefficients of determination were as follows: $r^{2}$ : 0.9997 (BZE) - linear regression equation $\mathrm{y}=0.0485 \mathrm{x}+0.4704 ; 0.9985(\mathrm{COC})$ - linear regression equation: $\mathrm{y}=0.0658 \mathrm{x}+0.9031$; $0.9993(\mathrm{CE})$ - linear regression equation: $\mathrm{y}=0.0665 \mathrm{x}$ -0.3015 .

A study for the analysis of cocaine obtained linear calibration curves (20-2000 ng/mL) with a determination coefficient of 0.9998 and with a linear regression equation of $\mathrm{y}=0.0046 \mathrm{x}+0.0014$ (Farina, Yonamine, Silva, 2002). Considering benzoylecgonine, a study performed by Oliveira and collaborators, showed tha the calibration curve was linear in the concentration interval assessed $(7.5-3200 \mathrm{ng} / \mathrm{mL})$, with $\mathrm{r}^{2}$ : 0.9916 and linear regression equation $\mathrm{y}=0,0045 \mathrm{x}+0,0985$ (Oliveira et al., 2016).

The method also obtained good linearity in a broad concentration range for all three analytes. The interval represents concentrations of cocaine and metabolites commonly found in urine samples of cocaine users (Williams et al., 2000).

Linearity assays (TABLE I) resulted in a coefficient of determination $\left(\mathrm{R}^{2}\right)$ higher than 0.99 for all three analytes, which makes the results satisfactory and in accordance with ANVISA and UNODC resolutions (ANVISA, 2012; UNODC, 2009). Moreover, the clean urine extracts obtained through solid phase extraction (SPE) had an impact on the technique selectivity. This is an important factor that contributed to a higher sensitivity, which is especially important for assessing cocaine metabolites. SPE is indeed a technique of greater sensitivity and specificity; its use is advantageous due to the fact it does not reque as many organic solvents as other extraction techniques, in addition to not forming emulsions during the extraction process, which interfere with the amount of analyte extracted (Moreau, Siqueira, 2016). According to Castro et al. (2012), the use of SPE for detection of drugs of abuse allows a good recovery and sensitivity, thus, reducing analysis interferences.

It has been shown that MTBSTFA as a derivatizing agent is significantly more efficient than BSTFA (Bonchev, 2017) and than other techniques such as perfluoroalkylation and alkylation (Maurer, 1992; Paul, et al., 1996) and also more efficient than other agents such as diazomethane (Yonamine, Silva, 2002). However, the use of BSTFA $+1 \%$ TMCS in the present study provided satisfactory results which served its purposes. The final values were below the cut-off values for BZE, COC and CE (150 ng/mL) as established by The Substance Abuse and Mental Health Services Administration (SAMHSA).

The results for intra and inter assay accuracy were satisfactory, since s at low analyte concentrations the results obtained were lower than $20 \%$, and at average and higher concentrations, the results were higher than $15 \%$, in accordance with international guidelines. The results related to $r$ precision obtained in the present study corroborate the values found in other studies, which also report the determination of cocaine and its metabolites in urine (Brunetto et al., 2005; Alvear et al., 2014; Berg et al., 2009).

The accuracy parameter accuracy (TABLE I) was determined by carrying out assays using three different concentrations with six determinations per concentration and evaluated alongside precision. Therefore, the values must remain between 80 and 120\% (ANVISA, 2012; UNODC, 2009).

Similar accuracy results were obtained by Chericoni and collaborators in a study that analysed cocaine and benzoylecgonine via GC-MS, which reported accuracy values for BZE of $107.8 \%$ and $100.8 \%$ for COC. The limits for these parameters were within the acceptable 15\% range (Chericoni et al., 2015).

The detection and quantification limits obtained using the technique herein described are acceptable, since the final values were below the cut-off values for BZE, COC and CE (150 ng/mL) (Killander et al., 1997). The Substance Abuse and Mental Health Services Administration (SAMHSA) also establishes that such values should be below a cut-off value; thus, the method herein proposed is in accordance with the international guidelines (Bush, 2008). 
The extraction method had recovery values ranging from $74.0 \%$ to $79.8 \%$ for BZE, $78.0 \%$ to $85.8 \%$ for COC and $83.0 \%$ to $91.5 \%$ for CE. According to UNODC (2009), the recovery of analytical techniques must not necessarily be $100 \%$. Lower values are acceptable, so long the method can be proven to be precise and accurate; moreover, the detection and quantification limits must be appropriate and in accordance with the purpose of the technique (UNODC, 2009).

Similar results for the analysis of benzoylecgonine were described by Oliveira and collaborators in a study whose authors validated a method for identifying drugs of abuse; the recovery values ranged from $72.7 \%$ to $84.6 \%$ (Oliveira et al., 2016). Garside and collaborators, on the other hand, used liquid phase extraction for analysis of cocaine via GC-MS in urine samples, and recovery was $48.8 \%$ (Garside et al., 1997).

The stability assays (Figure 1), as performed by comparing urine samples stored at $4-8{ }^{\circ} \mathrm{C}$ with others stored at $-20{ }^{\circ} \mathrm{C}$, showed that storage at inappropriate conditions of samples can lead to variations of analyte concentrations.

As seen in the chromatogram (Figure 2 - A), the retention times obtained for the analytes was $12.34 \mathrm{~min}$ for COC, $12.82 \mathrm{~min}$ for BZE and $13.17 \mathrm{~min}$ for CE. In order to confirm the presence of analytes (Figure 2 - B), mass specters for each analyte were obtained by identifying fragments $(\mathrm{m} / \mathrm{z}) 82,240$ and 361 for BZE, 182, 272 and 303 for COC, and 196, 272 and 317 for CE.

The technique herein described can be considered precise and accurate, since the three major analytes derived from cocaine metabolism could be successfully detected and quantified.
Elimination of cocaine is mostly determined by its biotransformation, which is very elaborate and complete; only small amounts of unaltered cocaine can be found in urine (usually lower than 10\%) (Alvear et al., 2014). Indeed, COC, which is chemically transformed to benzoylmethylecgonine, is quickly biotransformed into benzoylecgonine (BZE); this metabolite represents 29 to $45 \%$ of the urinary excretion of COC metabolites. Besides the major compound BZE, other biotransformation products, such as ecgonine, norcocaine and benzoylnorecgonine are also excreted. When in combination with ethanol, cocaethylene is formed, which is a very toxic metabolite (Alvear et al., 2014). Detection of cocaethylene in biological samples is important, since simultaneous use of ethanol and cocaine is a common practice of the drug users.

This study proposed a method for the simultaneous analysis of benzoylecgonine, cocaine and cocaethylene in urine, which was efficient and in accordance with the international guidelines. There are procedures published in scientific literature describing analysis of benzoylecgonine, however, in this manuscript, cocaine and cocaethylene were also taken into consideration during the validation process. The method herein described allows the use of smaller amounts of hazardous organic solvents when compared to other conventional extraction techniques. This method shall be useful for laboratories of clinical toxicology seeking to implement new and efficient analytical techniques aimed at analying cocaine and its metabolites.

TABLE 1 - Analytical parameters of the method developed for detection and quantification of cocaine and its biotransformation metabolites, as assessed by SPE/GC-MS*

\begin{tabular}{lccc}
\hline Analytes & BZE & COC & CE \\
\hline Recovery (\%) & 74 & 81.9 & 85.8 \\
Low concentration & 76.5 & 78 & 83 \\
Average concentration & 79.8 & 85.8 & 91.5 \\
High concentration & & & (continuing)
\end{tabular}


TABLE 1 - Analytical parameters of the method developed for detection and quantification of cocaine and its biotransformation metabolites, as assessed by SPE/GC-MS*

\begin{tabular}{llll}
\hline Analytes & BZE & COC & CE \\
\hline
\end{tabular}

Intra-assay precision (CV\%)

Low concentration

Average concentration

High concentration

\section{Inter-assay prcision (CV\%)}

Low concentration

Average concentration

High concentration

\section{Accuracy}

Low concentration

$1^{\text {st }}$ day
$2^{\text {nd }}$ day
$3^{\text {rd }}$ day

Average concentration

$$
\begin{aligned}
& 1^{\text {st }} \text { day } \\
& 2^{\text {nd }} \text { day } \\
& 3^{\text {rd }} \text { day }
\end{aligned}
$$

High concentration

$$
\begin{aligned}
& 1^{\text {st }} \\
& 2^{\text {nd }} \text { day } \\
& 3^{\text {rd }} \text { day }
\end{aligned}
$$

LOD $(\mathrm{ng} / \mathrm{mL})(\mathrm{CV} \%)$

LOQ (ng/mL) (CV\%)
9.5

7.8

8.1

10.3

12.3

98.1

97.9

99.2

97.5

99.2

103.3

104.8

102.5

99.6

$15(\mathrm{CV}: 12.3)$

20 (CV: 14.7)

*SPE/GC-MS: solid phase extraction/gas chromatography - mass spectrometry

BZE: low concentration: $150 \mathrm{ng} / \mathrm{mL}$, average concentration: $800 \mathrm{ng} / \mathrm{mL}$, high concentration: $3000 \mathrm{ng} / \mathrm{mL}$.

COC and CE: low concentration $50 \mathrm{ng} / \mathrm{mL}$, average concentration: $500 \mathrm{ng} / \mathrm{mL}$, high concentration: $2000 \mathrm{ng} / \mathrm{mL}$;

$\mathrm{CV}$ : coefficient of variation; LOQ: limit of quantification; LOD: limit of detection.
5.4

14.6

12.8

7.2

10.3

5.9

8.9

7.6

11.9
8.7 


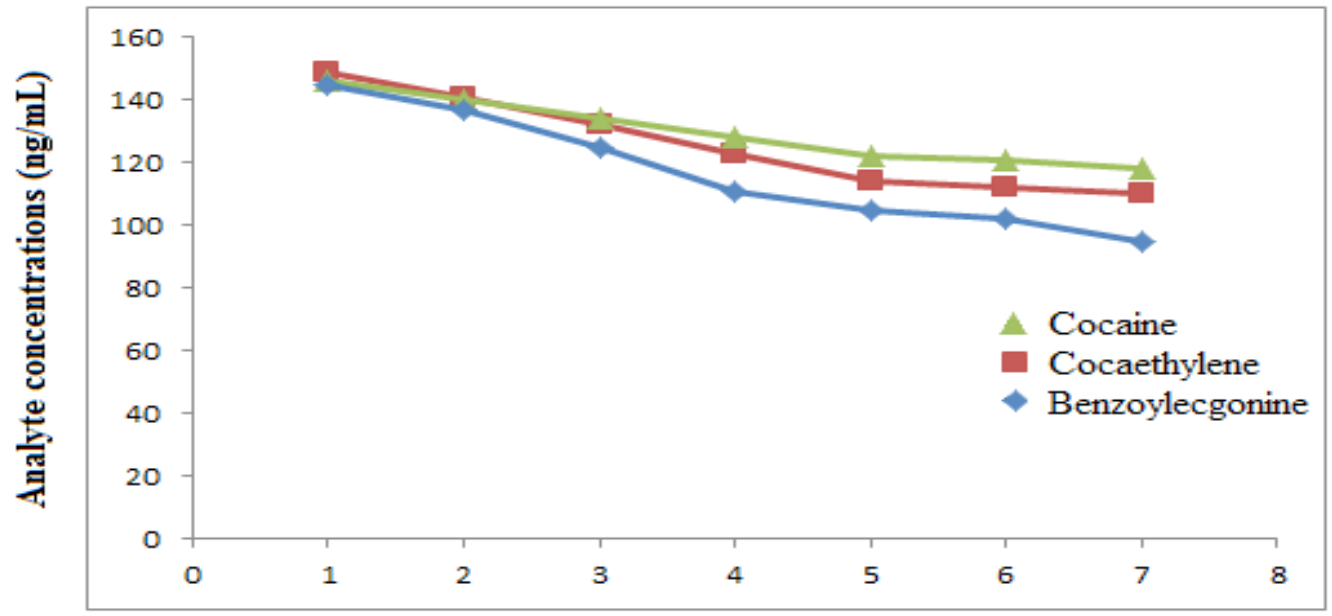

Days of storage

FIGURE 1 - Results for the stability assay of benzoylecgonine, cocaine and cocaethylene in urine samples stored at $4-8{ }^{\circ} \mathrm{C}$. Average concentration values $(n=3)$ obtained throughout 7 days of storage.



FIGURE 2 - Chromatogram and mass specters obtained by SPE/GC-MS in urine samples.

$\mathrm{A}=$ Positive samples (reference standard): negative urine samples containing added standards of BZE, COC and CE. (1) COC peak, (2), BZE peak, (3), CE peak.

$\mathrm{B}=$ Positive sample, quantifier and qualifier Íon (m/z) of BZE $(82,240,361), \operatorname{COC}(182,272,303)$ and CE $(196,272,317)$. 


\section{ACKNOWLEDGEMENTS}

To Decit/SCTIE/MS; CNPq; Araucaria Foundation and SESA-PR for their financial support.

\section{REFERENCES}

ANVISA - Agência Nacional De Vigilância Sanitária. Anvisa. Resolução - RE no 27, de 17 de maio de 2012. Guia para Validação de Métodos Analíticos e Bioanalíticos. 2012.

AlvearE, VonBaerD, MardonesC, Hitschfeld A.Determination of Cocaine and Its Major Metabolite Benzoylecgonine in Several Matrices Obtained from Deceased Individuals with Presumed Drug Consumption prior to Death. J Foren Legal Med. 2014; 23. Elsevier Ltd: 37-43.

Berg T, Lundanes E, Christophersen AS, Strand DH. Determination of Opiates and Cocaine in Urine by High $\mathrm{pH}$ Mobile Phase Reversed Phase UPLC-MS/MS. J Chrom B: Anal Techn Biomed Life Sci. 2009877(4):421-32.

Bonchev G. An optimized gc-ms method for identification of cocaine and its major metabolites. Journal of IMAB - Annual Proceeding (Scientific Papers). 2017 Apr-Jun;23(2).

Brunetto MR, Cayama YD, García LG, Gallignani M, Obando, MA. Determination of Cocaine and Benzoylecgonine by Direct Injection of Human Urine into a Column-Switching Liquid Chromatography System with Diode-Array Detection. J Pharm Biomed Anal. 2015;37(1):115-20..

Bush DM. The U.S. Mandatory Guidelines for Federal Workplace Drug Testing Programs: Current Status and Future Considerations. Forens Sci Int. 2008;174(2-3): 111-19.

Castro AL, Tarelho S, Silvestre A, Teixeira HM. Simultaneous analysis of some club drugs in whole blood using solid phase extraction and gas chromatography-massspectrometry. Journal of Forensic and Legal Medicine. 2012;19(2):77-82.

Chasin AAM, Chasin M, Salvador MC. Validaçao de Métodos cromatográficos em análises toxicológicas. Rev Farm Bioquim Univ S Paulo, 1994;30(2):49-53.

Chericoni S, Stefanelli F, Da Valle Y, Giusiani M. A Direct Aqueous Derivatization GSMS Method for Determining Benzoylecgonine Concentrations in Human Urine. J Foren Sci. 2015;60(5):1355-59.

De Brabanter N, Gansbeke WV, Hooghe F, Van Eenoo P.Fast Quantification of 11-nor-??9-Tetrahydrocannabinol9-Carboxylic Acid (THCA) Using Microwave-Accelerated Derivatisation and Gas Chromatography-Triple Quadrupole
Mass Spectrometry. Forenc Sci Int. 2013;224(1-3). Elsevier Ireland Ltd: 90-95.

Farina M, Yonamine M, Silva OA. One-step liquidliquid extraction of cocaine from urine samples for gas chromatographic analysis. Forensic Science International. 2002;127(3),204-207.

Follador MJD, Yonamine M, Moreau RLM, Silva OA. Detection of Cocaine and Cocaethylene in Sweat by SolidPhase Microextraction and Gas Chromatography/mass Spectrometry. J Chrom B: Anal Techn Biomed Life Sci. 2004;811(1 SPEC. ISS.):37-40.

Garside D, Goldberger BA, Preston KL, Cone EJ. Rapid Liquid-Liquid Extraction of Cocaine from Urine for Gas Chromatographic-Mass Spectrometric Analysis. J Chrom B: Biomed Appl. 1997;692(1):61-65.

Killander J, Torre R, Segura J, Zeeuw R, Williams J. Recommendations for the Reliable Detection of Illicit Drugs in Urine, with Special Attention to the Workplace, in the European Union (December 1996). The Toxicology Experts' Working Group. Scand J Clin Lab Invest. 1997;57(2):97-103. http://www.ncbi.nlm.nih.gov/pubmed/9200267.

Maurer HH. Systematic toxicological analysis of drugs and their metabolites by gas chromatography-mass spectrometry. Journal of Chromatography B: Biomedical Sciences and Applications. 1992:580(1-2):3-41.

Moreau RLM, Siqueira MEPB. Ciências farmacêuticas: toxicologia analítica. 2. ed. Rio de Janeiro: Guanabara Koogan(2015).

Oliveira SCW, Franco SE, Takai LY, De Oliveira TF, Yonamine M. Estimation of Measurement Uncertainty in Benzoylecgonine Analysis in Urine by GC-MS. Braz J Foren Sci, Med Law Bioeth. 2016;5(2):215-231.

Paul BD, Dreka C, Summers JL, Smith ML. One-step esterification of benzoylecgonine with dimethylformamidedipropylacetal or dimethylformamide-diisopropylacetal in the presence of pyridine. J Anal Toxicol. 1996;20:506-508.

UNODC (United Nations Office on Drugs and Crime). 2017. World Drug Report 2017. Global Overview of Drug Demand and Supply. https://www.unodc.org/wdr2017/field/ Booklet_2_HEALTH.pdf.

Williams RH, Maggiore JA, Shah SM, Erickson TB, Negrusz A. Cocaine and Its Major Metabolites in Plasma and Urine Samples from Patients in an Urban Emergency Medicine Setting. J Anal Toxicol. 2000;24:478-81. 
Validation of a method for simultaneous analysis of cocaine, benzoylecognine and cocaethylene in urine using gas chromatography-mass spectrometry

World Health Organization. WHO Technical Report Series 823. WHO Expert Committee on Specifications for Pharmaceutical Preparations: Thirty Second Report.1992. World Health Organization.

Yonamine M. A Saliva Como Espécime Biológico Para Monitorar O Uso de Álcool, Anfetamina, Metanfetamina, Cocaína E Maconha Por Motoristas Profissionais. 2004. http://www.teses.usp.br/teses/disponiveis/9/9141/tde03072008-093347/pt-br.php.
Yonamine M, Silva OA. Confirmation of cocaine exposure by gas chromatography-mass spectrometry of urine extracts after methylation of benzoylecgonine. J Chromatogr B Analyt Technol Biomed Life Sci. 2002;773(1):83-87.

Received for publication on $20^{\text {th }}$ August 2018 Accepted for publication on 01 ${ }^{\text {st }}$ April 2019 